Discourse and Communication for Sustainable Education, vol. 8, no. 2, pp. 5-16, 2017

\title{
Design Criteria for Visual Cues Used in Disruptive Learning Interventions Within Sustainability Education
}

\author{
Tanja Tillmanns, Charlotte Holland, and Alfredo Salomão Filho \\ Dublin City University, Ireland
}

\begin{abstract}
This paper presents the design criteria for Visual Cues - visual stimuli that are used in combination with other pedagogical processes and tools in Disruptive Learning interventions in sustainability education - to disrupt learners' existing frames of mind and help re-orient learners' mind-sets towards sustainability. The theory of Disruptive Learning rests on the premise that if learners' frames of mind or frames of reference can be disrupted (in other words, challenged), then learners' mind-sets can be re-oriented towards sustainability, and indeed learners can be motivated to engage in change agency for sustainability. The use of Visual Cues thus unsettle or challenge learners' mind-sets, and in doing so, set them on the pathway towards re-orientation in becoming more sustainability oriented, and/or in motivating engagement in sustainability change agency. The findings form part of a broader research study on ESD conducted in a higher education institution in Ireland within an undergraduate degree of teacher education. Kathy Charmaz' Constructivist Grounded Theory approach guided the entire study, resulting in the articulation of the theory of, and processes within, Disruptive Learning. This paper presents design criteria for Visual Cues that were articulated through a thematic analysis approach from data emerging from reflective diaries, follow-up interviews, audio recordings and observational notes. The findings from this study in respect of design criteria state that Visual Cues must disrupt rather than disturb; must represent (have impressions of) real life contexts, scenarios, practices or events; must provoke controversy; must contain a visual stimulation; and can have a critical question.
\end{abstract}

Keywords: Disruptive Learning, Visual Cue, pedagogy, sustainability education, higher education.

\section{Introduction}

One of the most valuable and powerful public goods is sustainability - an inherent solicitude for the survivability of life on Earth as we know it. To tap into the potential of this public good, a shift towards, or a consideration of, a relational worldview is urgently required. Anthropocentrism or human-centeredness shapes Western value systems, resulting in the prioritisation, protection and promotion of human interests 
and well-being at the expense of non-human things. The evidence of anthropogenic causes of contemporary crisis generates pressure on education to re-orient human practices and actions (Barrett et al., 2017). Unsustainable practices highlight the necessity to take into consideration alternative paradigms (Pipere, 2016). Potentially, holistic thought processes support the understanding of humankinds' position in the whole ecosystem, and scholars increasingly suggest the importance of 'disrupting' anthropocentric perspectives and/or dispositions. In this sense, Barrett and his colleagues (2017) argue that "the more-than-human as agent is essential for disrupting the anthropocentric privilege that dominates" (p. 134) the education system. Jickling and Sterling (2017) also emphasise the need to disrupt dominating assumptions in educational thinking, while Jickling (2017) argues that the creation of "education experiences that are held, felt, and disruptive might just be the basis for learning that is, indeed, transformational" (p. 28). Moreover, the future of humanity relies on the reorientation of each individual (Zygmunt, 2016) through an exploration of one's values and worldviews based on both self-knowledge and knowledge about others (Valk \& Tosun, 2016).

As traditional pedagogy is also based on the humanistic and anthropocentric tradition (Ferrante \& Sartori, 2016), educators should become 'artistic rebel teachers' who challenge individualistic anthropocentrism (Blenkinsop \& Morse, 2017), as "ESD [Education for Sustainable Development] essentially starts with and revolves around re-embedding SD [Sustainable Development] in life and the act of living" (Eernstman $\&$ Wals, 2013, p. 1657). This requires teachers to become change agents for sustainability, then, educating students to become change agents. As there is no blueprint of a sustainable life or sustainability values, a change agent for sustainability is ones' own teacher. In this respect, Gregory (2014) elaborates that

for the classroom community and the larger society this kind of education aims at democratic reconstruction. For the individual, this kind of education aims at demystification about the power arrangements of one's school, family, neighborhood, workplace and state. To be demystified is to become aware of the kind of person one has become by participating in these relationships and institutions, how one in turn contributes to status quo power systems, and the possibilities for exercising one's agency - especially with others similarly situated - to disrupt and reinvent them (p. 27).

This paper presents the design criteria for Visual Cues - a visual stimulus that can be used (in combination with other pedagogical processes and tools) to disrupt learners' existing frames of mind, stimulating deep learning and re-orientation of frames of mind towards becoming more sustainability oriented, and/or motivating engagement in sustainability change agency.

\section{Research Context}

The findings outlined in this paper emerged from a broader research study on sustainability education conducted in a higher education institution in Ireland within an undergraduate degree of teacher education. Kathy Charmaz' (2006) Constructivist Grounded Theory approach, a systematic methodology in the social sciences, guided this entire study. The contributions to knowledge of this study were twofold, resulting in the articulation of the theory of, and processes within, Disruptive Learning. Disruptive 
Learning rests on the premise that if learners' frames of mind or frames of reference can be disrupted (in other words, challenged), then learners' mind-sets can be re-oriented towards sustainability, and indeed learners can be motivated to engage in change agency for sustainability. The theory of Disruptive Learning thus has the potential to inspire pedagogic interventions that can activate transformations in self and of self, particularly re-orientating mind-sets towards sustainability. The theory of Disruptive Learning aims to initially unsettle (but not disturb) participants, and by using pedagogic processes and tools, it consciously strives to avoid learners being left in a state of disruption. The premises underpinning Disruptive Learning would also counsel against engagement in any activity that has even a low risk of causing mental or emotional disturbance to learners. Disruptive Learning does not belong to any 'signifier bandwagon'. It attempts to disrupt and stimulate visions to re-orient self in the context of the anthropocene, global challenges and crisis. Disruptive Learning is fully activated through pedagogic processes, offering opportunities for deep consideration and sharing of perspectives, values, and worldviews.

In the broader study, it was shown that Disruptive Learning can be facilitated through the design of pedagogic interventions, heretofore referred to as Visual Cue interventions, inspired by Mezirow's (1997) Theory of Transformative Learning, that encompass three dimensions - the first of which involves triggering disruption, the second rational discourse and the third critical reflection. The focus of this paper is to explain the design criteria of the Visual Cues that were used to trigger disruption. The pedagogical processes that enable learners to move beyond initial disruption are an important aspect that will be discussed in another publication.

Within this study, we used a thematic analysis approach (Braun \& Clarke, 2006) for the identification of the design criteria of Visual Cues. For this part of the analysis, we relied on data emerging from reflective diaries, follow-up interviews, audio recordings of group discussions, and observational notes taken by an observer during the interventions.

\section{What is a Visual Cue?}

A Visual Cue is a visual stimulus, designed to disrupt or challenge mind-sets of students, that may take the form of image or video and may be combined with a critical question (as was mainly the case in this study) to stimulate deeper forms of learning. The Visual Cue aims to stimulate reflection on and deeper thinking about assumptions, expectations, values and beliefs that influence dominant ways of thinking, feeling and acting in contemporary Western societies, inviting students to question their current norms, perspectives and dispositions that have resulted in non-sustainable Western livelihoods. The underpinning assumption is that Western societies are estranged from the wider global community and are to greater extents unaware of the causes or effects of anti-social/environmental behaviours (Cook, Cutting \& Summers, 2010). Visual Cues interventions mark the genesis of the re-orientation process, necessary to initiate higher order or deeper forms of learning. This research has provided evidence that the Visual Cues used in this study stimulated disruption within the learner/s, and thus, acted as disorienting dilemmas in a classroom-based setting and supporting a personal connection with the presented scenario. The extent to which Visual Cues facilitated disruption in state of mind was subjective to each learner. However, Visual Cues were shown to have 
directed the attention of students to sustainability issues, values-bases, and worldviews, which in turn enabled students to question their own values and worldviews.

The exemplified Visual Cues comprise six different scenarios, requiring students to critically consider different issues, such as: the consequences of humans' far reaching imprint/impact on the environment (Elephant Cue); the collective responsibility of the European refugee crisis (Boy Cue); poverty in developed contexts of the world (Homeless Man Cue); the context of human tissue or human organ growth on animals (Vacanti Mouse Cue); whether they would engage in a particular tribal cultural practice to save vulnerable animal ('Baboon' Cue); and finally, to draw critical connections within the thematic area of sustainability (Leopard Cue). The table below describes the nature of, and the sustainability principles and the thematic areas within, each Visual Cue.

\section{Table 1}

Overview of Visual Cue Examples

\begin{tabular}{ll}
\hline Visual Cue: & Elephant Cue \\
\hline Description: & $\begin{array}{l}\text { The image shows an elephant standing in its natural habitat and has } \\
\text { graffiti sprayed over his body. }\end{array}$ \\
\hline Trigger question & $\begin{array}{l}\text { What imprint do YOU make on the environment? } \\
\text { \& Visual Source: } \\
\text { Source: http://adsoftheworld.com/media/print/wwf_biodiversity_and_- } \\
\text { biosafety_awareness_elephant }\end{array}$ \\
\hline Sustainability & $\begin{array}{l}\text { Respect \& Care for the community of life (interdependency of human/ } \\
\text { principles: }\end{array}$ \\
& $\begin{array}{l}\text { nature and human/animals); Ecological Integrity; Fragility of Nature's } \\
\text { balance; Possibility of Ecocrisis; Anti-anthropocentrism; Democracy, }\end{array}$ \\
\hline Thematic areas: & $\begin{array}{l}\text { Far-reaching consequences of human actions on environment; Interde- } \\
\text { pendencies of sustainability cornerstones; Natural/Urban environment; } \\
\text { Graffiti as art/vandalism; Animal extinction; Animal poaching/hunting; }\end{array}$ \\
Animal rights
\end{tabular}


Sequel to Table 1.

Sustainability Respect \& Care for the community of life (interdependency of human/ principles: humans); Sociocentrism; Ecological integrity; Democracy, non-violence \& peace; Social \& Economical Justice

Thematic areas: $\quad$ Food wastage; Inequality in northern nations; Marginalised/vulnerable members of local communities; Inequality between northern and southern nations; Human rights

\begin{tabular}{|c|c|}
\hline Visual Cue: & Vacanti Mouse Cue \\
\hline Description: & $\begin{array}{l}\text { The image shows a mouse with a human ear growing on its back - more } \\
\text { commonly known as the Vacanti mouse (Cao et al. 1997), on the } \\
\text { shoulder of a young woman. }\end{array}$ \\
\hline $\begin{array}{l}\text { Trigger question } \\
\text { \& Visual Source: }\end{array}$ & $\begin{array}{l}\text { Would you allow a body part to be grown on an animal to improve your } \\
\text { appearance? } \\
\text { Source: https://bendinggenre.files.wordpress.com/2013/11/girl-with-ear.jpg }\end{array}$ \\
\hline $\begin{array}{l}\text { Sustainability } \\
\text { principles: }\end{array}$ & $\begin{array}{l}\text { Respect \& Care for the community of life (interdependency of human/ } \\
\text { nature and human/animals); Anti-anthropocentrism; Ecological integrity; } \\
\text { Rejection of Exemptionalism; Democracy, non-violence \& peace }\end{array}$ \\
\hline Thematic areas: & $\begin{array}{l}\text { Animal rights; Question consent of animals used for scientific advance- } \\
\text { ments; Animal testing; Science vs. nature; Vanity vs. well-being; Lifestyle } \\
\text { choices based on vanity or health; Genetically modified organisms }\end{array}$ \\
\hline Visual Cue: & 'Baboon' Cue \\
\hline Description: & $\begin{array}{l}\text { The image shows a woman from the Yanomami tribe breastfeeding both } \\
\text { a human baby and a baby monkey (Mark Edwards, Hard Rain project). } \\
\text { The title is a word play relating to 'baby' and 'baboon'. }\end{array}$ \\
\hline Trigger question & Would you breastfeed a baboon? \\
\hline Source: & Source: http://www.hardrainproject.com/admin_images/yanomami800.jpg \\
\hline $\begin{array}{l}\text { Sustainability } \\
\text { principles: }\end{array}$ & $\begin{array}{l}\text { Respect \& Care for the community of life (interdependency of human/ } \\
\text { human, human/nature and human/animals); Reality of limits to growth; } \\
\text { Anti-anthropocentrism; Fragility of nature's balance; Possibility of } \\
\text { eco-crisis; Ecological integrity; Democracy, non-violence \& peace; Social } \\
\text { and economical justice; Sociocentrism }\end{array}$ \\
\hline c areas: & $\begin{array}{l}\text { Comparison between Western and Yanomami cultures; Human rights of } \\
\text { indigenous people; Value of indigenous culture; knowledge for environ- } \\
\text { mental protection and human well-being; Impact of global industrial } \\
\text { practices }\end{array}$ \\
\hline Visual Cue: & Leopard Cue \\
\hline Description: & $\begin{array}{l}\text { The video was created by Banksy. It shows what appears at first glance a } \\
\text { leopard laying on a piece of wood in a room. The camera man touches } \\
\text { the leopard before showing the front of the leopard, which reveals only a } \\
\text { coat. }\end{array}$ \\
\hline Trigger question & No trigger question \\
\hline \& Visual Source: & Source: https://www.youtube.com/watch?v=6IpriP5Bl20 \\
\hline $\begin{array}{l}\text { Sustainability } \\
\text { principles: }\end{array}$ & $\begin{array}{l}\text { Respect \& Care for the community of life (interdependency of human/ } \\
\text { nature and human/animals); Ecological integrity; Democracy, non- } \\
\text { violence \& peace; Anti-anthropocentrism }\end{array}$ \\
\hline Thematic areas: & $\begin{array}{l}\text { Needs vs. wants; Animal waste; Quality of life and material sufficiency in } \\
\text { a finite world; Animal rights; Questioning concept of Zoo; Endangered } \\
\text { species }\end{array}$ \\
\hline
\end{tabular}




\section{Design Criteria for Disruptive Visual Cues}

We will now explain in detail, using examples from the design process of this research, the five design criteria of Visual Cues, namely, they must disrupt, rather than disturb; must represent (impressions of) real life contexts, scenarios, practices or events; must provoke controversy; must contain a visual stimulation; and, can have a critical question:

\begin{tabular}{ll}
\hline Visual & Must disrupt rather than disturb \\
Cues: & $\begin{array}{l}\text { Must represent (impression of) real life contexts, } \\
\text { scenarios, practices, or events }\end{array}$ \\
\cline { 2 - 2 } Must provoke controversy \\
& Must contain a visual stimulation \\
\hline Can include a critical question
\end{tabular}

Figure 1. Design criteria of Visual Cues

\section{Disrupt Rather Than Disturb}

Visual Cues need to be designed with the aim to disrupt not disturb learners' frames of mind. Educators designing Visual Cues should keep in mind that the intent of Visual Cues is to elicit or cause emotional reactions and/or cognitive disjuncture within learners by challenging or unsettling their existing mind-set/frames of reference. Visual Cues need to cause dissonance within learners, forcing them to take-stock of their emotional/ cognitive state of mind, and in turn, lead them to a heighted awareness of, or even questioning of, their existing perspectives and dispositions.

In the context of this study, a range of potential Visual Cues were reviewed not just by the researchers, but also by family, friends and colleagues, to clarify the potential of each Visual Cue to evoke emotional reactions, and to ascertain the appropriateness of these reactions. The findings of this study demonstrated that the selected Visual Cues were beneficial in enabling learners to 'connect with self', thus, in challenging or unsettling existing mind-set/frames of reference. Ultimately, as explained before, six Visual Cues were selected from over 50 possible cues that were reviewed. The following two examples of Visual Cues were excluded as they were very likely to result in disturbance rather that disruption of learners. The first of these was the video-recorded performance of Marion Laval-Jeantet and Benoit Mangin, called 'May the Horse Live in Me' (Fundación Telefónica, 2012). It is an extreme body art, where Marion slowly builds up her tolerance to animal bodies in order to transfuse horse blood into her system, symbolising the animal in human and questioning anthropocentric worldviews. The feedback from reviewers was that it had a very high likelihood of causing mental disturbance rather than mental disruption for the students. Another example is a video created by Eén, a Belgium TV show (Eén, 2016). It showed the backward production process of 'gummi bears' sweets. Towards the end of the video, a hanging lifeless large pig moves towards an assembly line's oven. In both examples, it would have been more likely that first year 
undergraduate students would have been unable to move beyond the potentially disturbing nature of these scenes, and thus would not be effective to integrate within Visual Cue intervention.

The findings have shown that Visual Cues should present a scenario that is less likely to be known to participants and is unfamiliar to daily life events or practices if it is to disrupt their existing frames of mind. In this sense, disruption is associated with the discovery of a new or unfamiliar idea, scenario or practice. The disruption of Visual Cues was also indicative of an experience that did not meet their expectations/prior frames of mind. Thus, students tended to be initially surprised, not being sure - initially of the meaning that they should attribute to the presented Visual Cue scenario, or how they should react to it.

The design of Visual Cues also depends on the demographics and prior knowledge of the target group. This group of learners were higher education students thus, there was greater flexibility in terms of what could be presented than if Visual Cue interventions were being deployed with younger learners in primary/post-primary settings.

Disturbance can be also avoided through the design of Visual Cues that are respectful to the personal contexts of individuals (religion, ethnicity inter alia) within the target group. We consciously avoided the design of Visual Cues interventions that could potentially result in discriminative comments towards marginalised individuals within the target group, such as Visual Cues centering on particular aspects of racial, gender or faith-based contexts.

Visual Cues are designed with the aim to evoke initial emotional reactions. Preferably, they should be unfamiliar to the target group, and consideration of its demographics is essential. It is pivotal that minorities do not feel disrespected or discriminated against during a Visual Cue intervention.

\section{Real Life Context, Scenario, Practice or Event}

Visual Cues must portray (or present impressions of) real life context, scenarios, practices or events. The first research phase contained 'the Horse Cue' (Tillmanns \& Holland, 2017), portraying a young man with the legs of a horse. The critical question was: 'would you grow an animal body part for the well-being of an animal?'. Most students' responses to the Horse Cue (which was photoshopped) pointed out the need for real life scenarios, as it appeared "too unrealistic". Consequently, we did not apply the Horse Cue in the second research phase. Furthermore, the Elephant Cue (also photoshopped by its creator) raised questions as to whether "the picture is genuine or photoshopped". However, as the Elephant Cue was of more realistic appearance and connected to the lecture content about "the interlinking elements of sustainable development", students critically considered the presented scenario and abstracted its meaning "of the far-reaching consequences of my actions on a global scale”.

Nevertheless, the Boy Cue is a reminder that if a Visual Cue deals with a sensitive issue, such as the tragic death of a child within the current European refugee crisis, it is advisable to consider artistic representations to stimulate critical consideration and reflection of the scenario, potentially avoiding emotional disturbances. When inquiring the appropriateness of the Boy Cue (which was an artistic representation of an original photograph of a real event), students thought that "the image was a good representation of the original image". While many participants were aware of the European refugee 
crisis, they acknowledged that the Visual Cue motivated them to "become more informed of the most recent Syrian refugee crisis". This research has shown that Visual Cues concerning current affairs can encourage individuals to form an opinion, become more critical, and discuss current events. Students participating in this study tended not to "voice their opinion" prior to their engagement with the Visual Cues. As a result, Visual Cues should not only portray unfamiliar scenarios, but also demonstrate (the impression of) real life contexts.

\section{Provoke Controversy}

Controversy increases the likelihood of polarised perspectives within the thematic areas, and thus has the potential to enable discourse. Table 1 includes an overview of the principles and thematic areas of the Visual Cues used in the interventions. The following extract from the audio recording of the Vacanti Mouse Cue discussion illustrates that students considered a variety of sustainability principles and related it to a variety of thematic areas within sustainability. This particular Visual Cue brought the following critical question: "Would you allow a body part to be grown on an animal to improve your appearance?

P1: I don't know, initially my reaction was 'no, it's unethical, it is cruel, its perverse of science', but then I thought 'oh hang on... what if I was involved in a car crash?' Would I say then 'oh god that is so cruel?'

P2: I thought that as well. If it was some kind of medical reason then, I would. But not for cosmetic reasons.

P3: The animal does not have a voice.

P4: Just because it is an animal does it not matter?

P5: There are cases where they grow the parts from stem cells and there is no animal involvement, so it is progressing, it is possible... they grown a cornea for a woman in a lab.

P4: I don't see it being the same, but my question really was: 'Would we agree more to it if it's an animal than if it's a buman?'

P7: I would say 'no', cause I feel strongly for animals...so no.

P8: We are human beings, we see ourselves as the master of beast, we think we can use animals for whatever we like, it is a new concept of animals having rights, rights in themselves.

The observational notes also showed that in designing or choosing Visual Cues that can be related to different sustainability issues, may stimulate controversy and support a rich exchange of various perspectives. It can further enhance the understanding of the "connectiveness [...] that everything is connected". One student noted during the interview that: "I don't think I saw things so much connected before; you hear about it but when you look at these Visual Cues you were able to tie in so many things into the same cue, which was really interesting". Therefore, educators should make sure to implement Visual Cues focusing on a variety of sustainability principles and thematic areas to provoke polarized perspectives within the thematic area. 


\section{Visual Stimulation}

For this research, Visual Cues consisted of images and videos. Visual material can be sourced from various areas of the public domain, such as art that is designed to raise public awareness - often found in social media (Kilaru, Asch, Sellers \& Merchant, 2014). For example, the visual content of the Elephant Cue was based on 'awareness advertisements' of a charity organisation. The Leopard Cue was based on the artwork of the street artist Banksy. The Homeless Man Cue entailed a video of a social experiment sourced from YouTube.

\section{Optional Use of a Critical Question}

Critical questions can be useful to relate Visual Cues to students' self and/or to ensure real life contexts. The Baboon, Homeless Man, Elephant, and Vacanti Mouse Cues have been related to self via the critical question that personally addresses the viewer. In the construction of questions, it is important to address the question directly to the learner by use of 'you' or 'yours' etc., as this enhances the likelihood of students personally connecting with the scenario and associated content to stimulate critical reflection of self in the context of sustainability. One student highlighted in her reflective diary that "the tagline makes it a more personal message, because of the use of the tagline where the 'You' is emphasized, it felt more directed at me personally".

Nonetheless, educators should keep in mind that visual material itself might relate to self, sustainability principles and/or thematic areas. For example, the tagline of the Boy Cue 'humanity washed ashore - shame, shame, shame', initiated critical reflection of whether self has a reason for shame regarding the refugee crisis. Here, the critical question of the Boy Cue connected the artistic representation back to the real-life context of the European refugee crisis, stimulating controversy. However, Visual Cues do not always need a critical question as the Leopard Cue demonstrates. We intentionally designed it without a critical question to avoid leading the discussion to certain issues of sustainability, but rather to examine to what extent the participants connected the Leopard Cue to a wider range of sustainability issues.

Depending on the nature of the visual material, it can be beneficial to include a critical question in order to relate the Visual Cue scenario to self and/or stimulate controversy.

\section{Conclusions}

In this paper, the design criteria of a critical component of Disruptive Learning interventions, namely Visual Cues, has been presented. In the context of betweenness of human and non-human, the use of Visual Cues within Disruptive Learning interventions can be used to stimulate learners to enter the process of re-considering own values, beliefs, and perspectives, aiming to establish a relationship, and co-evolve with, otherness. Education in the context of sustainability should provide opportunities for learners to critically engage with anthropocentrism or human-centeredness, shaping Western value systems. Furthermore, sustainability education should build the capacity in students to be aware of contemporary tensions or paradoxes, such as between modern and traditional; global and local; long-term and short-term considerations; the universal and the individual; and/or spiritual and material (Delors, 1996) to name but a few. Education should provide 
a safe space for exploring these tensions, motivating the re-orientation of existing frames of minds and actions based on an improved self-knowledge, and better understanding of the interconnectedness and interdependencies of all living and non-living entities on this planet.

Lewin (1948) emphasises that humans only change their values base if they perceive a need to change. Thus, learners of sustainability need to be disrupted, stimulating engagement with their own values in the context of sustainability in order to identify and re-orient anthropocentric values. Emotions are key to stimulate the process of ethics and values clarification (Eilam \& Trop, 2010) and are essential to give meaning to life, as they support the ability to transform and make sense of perception, thoughts, and actions (De Sousa, 1987). Moon (2008) defines 'emotional insight' as a type of learning that includes an unexpected, recognisable re-orientation of ones' individual outlook, but where processes that resulted in this shift are unconscious. The consideration of the affective domain in educating for sustainability fosters a personal attachment to sustainability and has the potential to influence future decisions (Shephard, 2015). Nevertheless, the use of the affective domain in higher education is limited (Dirkx, 2008). Similarly, art has been increasingly used to raise public awareness (Kilaru et al., 2014), but little consideration has been given to the usefulness of public art or work from the public domain for teaching and learning in higher education classroom contexts. Eernstman and Wals (2013) highlight the lack of consideration of art in the context of ESD. There is also a limited consideration of pedagogy that promotes "practices of self and world care, as well as all the forms of otherness with which we share processes of co-evolution, being aware of our ontological bias” (Ferrante \& Sartori, 2016, p. 184).

The inclusion of Visual Cues was inspired by Jack Mezirow's concept of a disorienting dilemma within his Theory of Transformative Learning, and represents one way of triggering disruption. In this sense, Visual Cues can be used to 'disorient' learners, evoking cognitive disjuncture within learners and/or emotional reactions through a personal connection with the scenario. Educators wishing to design Visual Cues need to take into consideration the five design criteria: Visual Cues must disrupt rather than disturb; represent (impressions of) real life contexts, scenarios, practices or events; and provoke controversy. The critical question accompanying the visual stimulation is optional.

Visual Cues illuminate one way of how anthropocentric perspectives and/or dispositions can be disrupted. The pedagogical processes that enable learners to move beyond initial disruption will be subject of a future publication articulating the Theory of Disruptive Learning. It is also important to note that the design criteria for Visual Cues (articulated within this paper) may not be exhaustive and future research might identify additional criteria for triggering disruption, and /or different ways in which to facilitate disruptive learning in ESD. 


\section{References}

Barrett, M.J., Harmin, M., Maracle, B., Patterson, M., Thomson, C., Flowers, M., \& Bors, K. (2017). Shifting relations with the more-than-human: six threshold concepts for transformative sustainability learning. Environmental Education Research, 21(1), 131-143, doi: 10.1080/13504622.2015.1121378

Blenkinsop, S., \& Morse, M. (2017). Saying yes to life: the search for the rebel teacher. In B. Jickling \& S. Sterling (Eds.). Post-sustainability and environmental education: remaking education for the future (pp. 49-62). Cham, Switzerland: Palgrave Macmillan.

Braun, V., \& Clarke, V. (2006). Using thematic analysis in psychology. Qualitative Research in Psychology, 3(2), 77-101, doi: 10.1191/1478088706qp063oa

Cao, Y., Vacanti, J. P., Paige, K. T., Upton, J., \& Vacanti, C. A. (1997). Transplantation of chondrocytes utilizing a polymer-cell construct to product tissue-engineered cartilage in the shape of a human ear. Plast Reconstr Surg, 100 (2), 297-302.

Charmaz, K. (2006). Constructing grounded theory: a practical guide through qualitative analysis. Los Angeles: SAGE.

Cook, R., Cutting, R., \& Summers, D. (2010). If sustainability needs new values, whose values? Initial teacher training and the transition to sustainability. In P. Jones, D. Selby, \& S. Sterling (Eds.) Sustainability education: perspectives and practices across higher education (pp. 313-327). London: Earthscan.

Delors, J. (1996). Learning: the treasure within. Report to UNESCO of the international commission on education for the twenty-first century. Paris: UNESCO.

De Sousa, R. (1987). The rationality of emotion. Cambridge, MA: MIT Press.

Dirkx, J.M. (2008). The meaning and roles of emotions in adult learning. New Directions for Adult and Continuing Education, 120, 7-18, doi: 10.1002/ace.9

Eén. (2016). Over eten - de weg van een snoepje [Video file]. Retrieved from https://vimeo.com/180163754

Eernstman, N., \& Wals, A.E.J. (2013). Locative meaning-making: an arts-based approach to learning for sustainable development. Sustainability, 5, 1645-1660, doi: 10.3390/ su5041645

Eilam, E., \& Trop, T. (2010). ESD pedagogy: a guide for the perplexed. The Journal of Environmental Education, 42(1), 43-64, doi: 10.1080/00958961003674665

Ferrante, A., \& Sartori, D. (2016). From anthropocentrism to post-humanism in the educational debate. Relations, 4.2 (November), 175-194, doi: 10.7358/rela-2016002-fesa

Fundación Telefónica. (2012). May the horse live in me: Tercer Premio VIDA 14.0 [Video file]. Retrieved from https://www.youtube.com/watch? $\mathrm{v}=\mathrm{Awz} 4 \mathrm{w} 22 \mathrm{tFHw}$

Gregory, M. (2014). Ethics education as philosophical practice: the case from Socratic, critical and contemplative pedagogies. Teaching Ethics, 15(1), 19-34, doi: 10.5840/ tej201410173

Jickling, B. (2017). Education revisited: creating educational experiences that are held, felt, and disruptive. In B. Jickling \& S. Sterling (Eds.) Post-sustainability and environmental education: remaking education for the future (pp. 15-30). Cham, Switzerland: Palgrave Macmillan.

Jickling, B., \& Sterling, S. (2017). Post-sustainability and environmental education: framing issues. In B. Jickling, \& S. Sterling (Eds.) Post-sustainability and environ- 
mental education: remaking education for the future (pp. 1-14). Cham, Switzerland: Palgrave Macmillan.

Kilaru, A.S., Asch, D.A., Sellers, A., \& Merchant, R.M. (2014). Promoting public health through public art in the digital age. American Journal of Public Health, 104(9), 1633-1635.

Lewin, K. (1948). Resolving social conflicts: selected papers on group dynamics. Washington, DC: Harper \& Brothers.

Mezirow, J. (1997). Transformative learning: theory to practice. New Directions for Adult and Continuing Education, 74, pp. 5-12.

Moon, J. (2008). Critical thinking: an exploration of theory and practice. London: Routledge.

Pipere, A. (2016). Envisioning complexity: Towards a new conceptualization of educational research for sustainability. Discourse and Communication for Sustainable Education, 7 (2), 68-91, doi: 10.1515/dcse-2016-0017

Shephard, K. (2015). Higher education for sustainable development. United Kingdom: Palgrave Macmillan.

Tillmanns, T., and Holland, C. (2017). Crafting pedagogical pathways that disrupt and transform anthropocentric mindsets of higher education students. In: W. Leal Filho, L. Brandli, P. Castro and J. Newman (Eds.) Handbook of Theory and Practice of Sustainable Development in Higher Education - World Sustainability Series (pp. 297-312). Springer International Publishing. doi: 10.1007/978-3-319-478685_19

Valk, J., \& Tosun, A. (2016). Enhancing religious education through worldview exploration. Discourse and Communication for Sustainable Education, 7(2), 105-117, doi: 10.1515/dcse-2016-0019

Zygmunt, T. (2016). Philosophy of sustainable development, Polish perspective. Discourse and Communication for Sustainable Education, 7(2), 43-51, doi: 10.1515/dcse2016-0015

Correspondence concerning this article should be addressed to Tanja Tillmanns, School of STEM Education, Innovation \& Global Studies, Institute of Education, Dublin City University, Ireland. Email: tanja.tillmanns2@mail.dcu.ie 